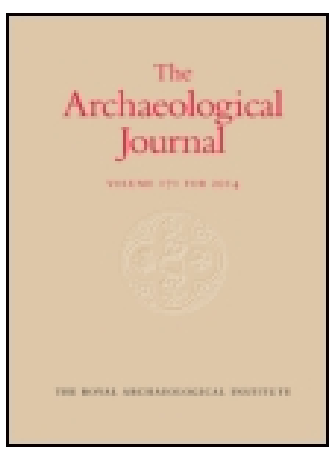

Archaeological Journal

\title{
On The Treatment Of Ancient Architectural Remains
}

\section{J. T. Micklethwaite F.S.A.}

To cite this article: J. T. Micklethwaite F.S.A. (1881) On The Treatment Of Ancient Architectural Remains, Archaeological Journal, 38:1, 352-360, DOI: 10.1080/00665983.1881.10851993

To link to this article: http://dx.doi.org/10.1080/00665983.1881.10851993

曲 Published online: 14 Jul 2014.

Submit your article to this journal ๘

Q View related articles $₫$ 


\section{ON THE TREATMENT OF ANCIENT ARCHITECTURAL REMAINS. ${ }^{3}$}

By J. T. MICKLETHWAITE, F.S.A.

It may seem that some apology is needed for bringing forward once more the well worn subject of "restoration." All that I can say about it has been said before by other people, as well as by myself. But, on the other hand, the mischief against which we protest still goes on, and finds defenders even amongst antiquaries, whose special studies ought to make them most alive to the harm of it. Such being the case, it is necessary to go on repeating our objections. A new gospel can only obtain a hearing from the world by persistent iteration, and until men are well farniliar with the sound, they will not, for the most part, take the trouble to understand it. There are subjects upon which we may wait patiently till time manifests the truth; but this is not one of them. Our ancient architectural remains are daily suffering from the misdirected zeal of their guardians, and unless we can obtain a hearing from them, there will soon not be much left worth contending for. A meeting like this seems to be a most suitable occasion for bringing the matier forward once more, and in it I know I may look for an intelligent audience, and $I$ hope a sympathetic one.

An ancient building may be regarded as a historic monument, as a work of art, or as a useful edifice. As antiquaries we have to do with it only in the first aspect, although we must take care not to lose sight of the other two. It is evident that the value of a historic monument depends entirely upon the genuineness of its condition. A mere fragment may be most precious, whereas a perfect work, containing much which really is what it pretends

1 Read in the Architectural Section at the Bedford Meeting, July 28, 1881. 
to be, may be worthless, because it is adulterated with forgeries, which can not be distinguished from the rest. No one would deny this with respect to written documents. We value the fragments of Babylonian history which scholars have lately decyphered for us, and we may wish that they were more perfect than they are. But if some man had set to work on his tablets and cylinders and neatly patched up all the missing portions and covered them with writing, " in exact conformity with the original," and then put forth the result, I do not think that the public recognition of his ingenuity would have taken the form of compliments upon the "thoroughness" of his "restoration."

Now old churches are as much historical documents as Babylonian cylinders are. But ever since their value as such first began to be appreciated, there have been those who have advocated and practised a falsification of them, just as much to be condemned as would be the forgery of ancient records. I do not speak of the destruction wrought under the name of "restoration" by incompetent architects and amateurs, but of the still worse mischief by men who thoroughly understood what they were doing, and who have not only destroyed much real old work, but have mixed up what they allowed to remain with forgeries of their own. The doctrine of " conservative restoration," as they are pleased to call it, which was preached by nearly all the leading architects of the last generation, has been more destructive than the axe of the Puritan, or the century and a half of churchwardenism which came after it. It is to the credit of this Institute that some of its members, and notably the late Mr. Petit, saw the danger, and protested against it from the first. But the evil went on.

The doctrine of "Restoration" depends upon the theory that each building belongs to a "period," and that the proper treatment of it is to take out everything which is not of that period and to replace it by new work, such as the architect believes might, could, would, should, or ought to have been there at that "period." The success of course varies with the skill of the architect, and often the interpolations are at once evident, and the harm confined to the destruction only. This, indeed, is generally 
the case as regards wood work, which nearly always carries its modernness plainly written upon it. But in stone, the most important of all building materials, many architects have produced work which, when the newness is gone off, can scarcely be distinguished from the old. Such a mixture of old and new takes from the former all its historic value, for who can tell of any portion of it whether it is due to the taste and skill of the ancient architect, or to the archreological learning of his brother of the nineteenth century?

But granting that the restored church-I speals of churches because the question becomes a practical one chiefly with respect to them, but the principle is the same for all buildings-granting, I say, that the church, when restored, is all that can be claimed for it, viz., an exact model of what it was in the thirteenth, or whatever century it may be, is it worth the old church which is sacrificed to make way for it? It is a fallacy to say of your old church that it belongs to any one "period." It belongs to all periods from the time when its first stone was laid, perhaps more than a thousand years ago, down to the present day. Its life has been continuous, and one of many changes. There is, perhaps, no portion of it which has not been rebuilt more than once, but the church is the same. Even that which has gone from it has left its influence behind, and may be traced through the later work by one who knows how to look for it. Thirty generations have come here for worship and the Sacraments, as their descendants still do ; and every generation has left its mark upon the builaing. Some have improved it, and some, it is true, have injured it; but even the marks of the harm they did may be full of interest; and those that have done nothing else have left us their tombstones. The place is alive with memories, and it is absurd to talk of its "period."

Now let us see what the "conservative restorer" does for it. The bulk of the walls is, we will suppose, of the favourite thirteenth century, which fixes its "period." The chancel was remodelled in the fourteenth century, and the east window was Flowing Decorated of four lights, but below it might be seen the cills of the original three lancets. With such evidence, of course, the end must be 
"restored," and if any doubts about it crept in they were entirely removed by the discovery of two or three stones of the "Early English" jambs in the wall upon taking out the fourteenth century window. The window nearest the altar on the south side of the chancel and that similarly placed in the south aisle of the nave were each of two lights, the former Decorated and the other Perpendicular, both inserted to give more light to the altars near them, and there was a similar insertion towards the west of the north wall; all these were clearly "innovations on the original design," and, as the architect pointed out, the tracery was somewhat out of repair, and there could be no doubt that there were lancets in these places, so the lancets were " restored." The like happened to a broad lancet near the south door which had been divided by a mullion and had tracery inserted in the head. Most of these windows retained fragments of painted glass of their respective dates, a good deal of that in the tracery being in situ. A few of the larger pieces are inserted in the window of the new vestry, and some in the fan light over the rectory front door; the others were not worth preserving and nobody knows what has become of them.

There was a difficulty about the west tower: it is in the early "Perpendicular" style and "quite out of keeping with the rest of the building;" but, unfortunately, funds were not forthcoming to rebuild it, so it is allowed to remain under a sort of protest. The clerestory of the nave was even later than the tower, "quite Debased," in fact; besides which there was the weathering, which shewed that there was once a high-pitched roof instead of the flat lead one. There could, therefore, be no hesitation about the removal of the clerestory; and the sale of the old lead nearly paid for a new stained deal roof of trussed rafters covered with neat Staffordshire tiles. The removal of the clerestory and the glazing of the restored lancet windows with "cathedral glass of assorted tints," has thrown a faint green light over the interior eminently calculated to foster devotion but a little suggestive of the Brighton Aquarium on a dull day.

Before the "restoration" the furniture of the church was of the most incongruous description. The pews were most irregular and of many dates, some-Late Perpendi- 
cular, some "Jacobean," and so on, to modern times. These have given place to neat uniform open benches of varnished pine. There was a large pulpit dated 1632, with a sounding board of the same date. This has given place to a more appropriate structure of Caen stone with pillars of Cornish serpentine. In the chancel arch stood an old rood screen, very late and out of repair. As it was out of keeping with the church and blocked out the view of the restored chancel, it was taken away and parts of it may now be seen made into a cupboard in the vestry. There were two ancient effigies, but so broken as not to be thought worth preserving. They are now on a rockery in the rectory garden. The other monuments were all of the "Pagan" sort, and were of course removed. A neat tile floor replaces the old one, which was made up almost entirely of gravestones, many of which were broken and very shabby. Proper attention has been given to warming and lighting, and the "restored" church is what the newspapers call " one of the handsomest in the county." But somehow, in spite of its merits, it is found to be a very dull affair and we soon have had enough of it. The fact is that its history has all gone and it has become a new building. It may have merit, but that merit is not of a sort which appeals to antiquaries. The church may be more useful than it was and even possibly more more beautiful, but it is no longer as it used to be-the living witness, and it may be the only witness, of the prosperity and adversity, the joys and the sorrows, the faith and the passions which have affected the men of that parish for many past centuries. The loss of such a witness is as grievous as it is irrevocable, although at present comparatively few seem to feel it. Men generally appreciate their loss where an ancient parish church has been replaced by one of the miserable edifices of the later Georgean period. Unless I am greatly mistaken some of our "conservatively" restored buildings will, before long, excite feelings of the same sort.

But it may be asked, Do churches exist simply as historical monuments? and are not the decency of the services and the convenience of the worshippers the first points to be considered? This brings me to the main subject of my paper. There are men who, disgusted by 
the reckless and ignorant destruction wrought by the " restorers," have condemned all alterations of ancient buildings, and insisted that nothing should be done to them except what is absolutely necessary to preserve them from ruin. But I am not one of them. The present generation have as much share in their church as any of the past, and have as much right as they to alter it to suit their needs and tastes. What gives an old church an interest which is shared by few other ancient relics is that it is a still living monument, and I hold that to take from it this quality is only in degree less harmful than to obliterate the record of its past life. Our duty is not only to preserve, but, as occasion calls, to continue the history.

Monuments, such as tombs, whose sole function is, and has been from the beginning, only existence, and those again whose use is now gone with the circumstances which called them into being, belong to a different class. Their record is finished, and our duty towards them is simply to protect and preserve them. If they are imperfect, we must accept them in their imperfection. To replace missing or defective parts of a thing which we still want to use is right and sensible. But to do the like to a thing without use, upon pretence of bringing it back to its original state, is absurd. What is gone is gone, and you can no more replace it than you can call back last week. When you have done your best at " restoring" a thing you have only produced a conjectural model of what it was, and you must almost certainly have destroyed some of the evidence upon which your "restoration" was based. It may be well sometimes to have models of ancient objects made, but the originals themselves should not be mutilated to produce them.

But to return to the question of churches. The first step towards a right treatment of them is to get rid of the period delusion. A church is dilapidated and inconvenient, and perhaps even unseemly. By all means let it be repaired and made decent and convenient. But let it be done with a due respect to the building and what it has witnessed. Do not try and make it look like a new church just imported from the thirteenth century ; but let it show that it has stood ever since the thirteenth 
century, and has passed through times both good and evil in its long life from then till now. All this may be if the work is done in the right way, and yet the requirements of our time need not be overlooked.

An architect who has to deal with an old church must begin by searching out its history, and must learn by what steps it came to be what it is, bearing in mind that history did not stop in the thirteenth or even in the sixteenth century, and that nothing is to be condemned as a disfigurement or mutilation merely on account of its date. Next let him arrange his alterations so as to take away as little as may be. It is often impossible but that there shall be some loss, but let it be only of that which is least worth keeping. Lastly, let the architect design his additions so that they may be in harmony with the old, but not make believe to be other than what they are. Let them be exactly what modern requirements call for, and let their date be plainly upon them. Till of late this was done naturally by every man doing his work, as a matter of course, in the style of his own time; but now we hure unfortunately no common style, and each man has to make or select one for himself. Work done in old churches must now be designed upon a study of old churches; but let us avoid in every case any direct reproduction of what may already be thers. Where symmetry demands a general accordance between the old and the new, as, for example, where a new arcade is to be added to a nave which now has only one aisle, or where new pews have to range with old ones, the general design may be followed and the difference marked in the details; and, as a general rule, it is well that modern additions and repairs should be in a different material from the old.

It is not necessary to protest now against the barbarous scraping and reworking which has destroyed so much old work. The "conservative restorers" have at least the merit of having put a stop to that, except in the hands of men who are too ignorant to be reached by anything that either they or we can say. But old plaster needs protection. Old rubble walls were never intended to be exposed on the inside, still less to have their rudeness intensified by pointing with dark mortar.

Sometimes, when a church is being enlarged, it may be 
necessary to remove objects which we do not wish to destroy. In such cases it is quite proper to set them up again in other positions-by preference, in the new work. But, wherever they are put, the fact of their removal should be marked in some way, either by their position or even by an actual inscription. For it should be remembered that the position of a thing is as much a part of its history as its form. The "restorers" generally have failed to understand this, and some even good men think they have done no harm to a thing so long as they have not destroyed its parts. Many a church has its history hopelessly confused by windows and screens, and the like being removed and cunningly fitted to places to which they do not belong. If a thing must be moved, as sometimes cannot be helped, the removal must be openly and honestly done, and no lies told about it.

Our present services are sufficiently near to the old ones to make mediæval arrangements and the principal objects of medireval furniture well suited to modern use, and these therefore may need judicious repair. Other objects the use of which has passed away should be left as they are. If perchance they are in such a condition that to leave them exposed would be unseemly, there is no harm in covering them up, but nothing in the way of "restoration" should be done to them. The like too of old tombs and all that belongs to them as their railings and heraldic appendages.

Those whose notions of "conservative restoration" permit them to retain fifteenth century work, too frequently think it a duty to destroy everything which is later than the Reformation. ${ }^{1}$ This is a most serious mistake. Much excellent work was done in the seventeenth century, both before and after the Puritan usurpation. Pulpits of these times were lately common, and some still remain, as do a few good reredoses of that and the succeeding century. These and many other things, which I need not name separately, all go to make up the life of the church. They are good in themselves, far better than the Cockney Gothic affairs, which have so

1 I have observed it as rather singular that this passion is strongest in Low Churchmen. 
often usurped their places, and they serve their respective purposes thoroughly well.

Some things, as the deal box pews of fifty years ago, and many stained and varnished "Gothic" abominations of the last three decades, are by their own wretched meanness unworthy of a place in the church at all, and and we may justly remove them because they ought never to have been admitted. This liberty, however, is one which must be used with caution. It does not extend to old gravestones and monuments, whatever be their quality. Many recent monuments are really offensive in design, and sometimes in position, but they should not be destroyed, nor, as is too often done, cut down, in order to lessen their size. They are too important a part in the record of the church to be lightly thrown away, and they should not only be preserved, but preserved unaltered. In extreme cases it may be right to cover them up, or to remove them to less objectionable sites, in which last case, some record of the removal should be left in their old places.

As for new work, it is perfectly right to put in anything which is either needed to suit modern requirements, or which our modern sense of propriety demands. The late revival in the Church has sreated many new wants, the satisfying of which affords ample opportunity for us to add our share to the history. Let all we do be the very best we can produce, and the value of it will be of the same sort as of the old. Posterity will thank us for it, and many think the chapter added in our time not the least interesting of the whole. 